\title{
Etiopathogenesis of Peptic Ulcers and Prostaglandin
}

\section{Relationship}

\section{Peptik Ülserlerin Etiyopatogenezi ve Prostaglandin Iliş̧kisi}

\author{
Aykut Ulucan \\ Bingöl Üniversitesi, Sağhle Hizmetleri Meslek Yüksekokulu, Tıbbi Hizmetler ve Teknikler Bölümü, Patoloji \\ Laboratuar Teknikleri Programı
}

\begin{abstract}
Peptic ulcer disease, usually seen in the stomach and proximal duodenum, is a disease that can be seen in individuals of different age groups due to a wide variety of infectious and non-infectious causes. The understanding of the etiopathogenesis of peptic ulcer disease is an important factor in the prevention, treatment, and management of this disease. Although there are several factors known to cause gastric ulcers, the mechanism of mucosal injury in the stomach related to gastric ulcers has not been fully clarified. Attempts to protect against a variety of environmental factors of gastric mucosa through prostaglandins play an active role in the protection of gastric ulcer. Numerous investigations have been conducted on gastric injury studies using necrotizing agents, nonsteroidal anti-inflammatory drugs and cold restriction stress models for the protective effect of some prostaglandins in the stomach. This allows removal of the gastric mucosa prostaglandin E2 in the development and progression of peptic ulcers has been shown to be a significant etiological factor. In light of all this information, the goal of this review is to discuss the etiopathogenesis of peptic ulcers and the prostaglandin relationship as a whole and thus to provide the researchers with a thorough knowledge of future studies. In conclusion, it can be said that prostaglandins are directly or indirectly related to some ulcerogenic and protective factors, especially stress, hormonal response, gastric acid, and mucus, and they also play important roles in the etiopathogenesis of peptic ulcer disease.
\end{abstract}

Key Words: Stomach, Prostaglandin E2, Stress, Gastric acid, Mucus

\section{Introduction}

Peptic ulcer is a heterogeneous illness with multifactorial etiology and is one of the largest general inveterate diseases among working-age adults (1). Despite the major developments in the understanding of peptic ulcer disease, its etiology has not been fully clarified. The main physiopathological theory of the formation of peptic ulcers is the deterioration of the

\begin{abstract}
ÖZET
Genellikle mide ve proksimal duodenumda görülen peptik ülser hastalığı, çok çeşitli enfeksiyöz ve non-enfeksiyöz nedenlere bağlı olarak, değişik yaş gruplarındaki bireylerde görülebilen bir hastalıktır. Peptik ülser hastalığının etiyopatogenezinin anlaşılması, başlıca bu hastalıktan korunmada ve hastalı̆ı̆n tedavisinin yönlendirilmesinde önemli bir unsurdur. Günümüzde gastrik ülserlere neden olduğu bilinen çeşitli faktörler olmasına rağmen, gastrik ülserler ile ilişkili olarak midedeki mukozal hasar mekanizması tam olarak aydınlatılamamıştır. Prostaglandinler aracılığıyla mide mukozasının çok çeşitli çevresel faktörlere karşı korunmaya çalışılması, gastrik ülser hastalı̆ı̆ndan korunmada merkezi bir rol oynar. Bazı prostaglandinlerin midedeki koruyucu etkisine yönelik, nekrotizan ajanlar, non-steroid antienflamatuvar ilaçlar ve soğuk kısıtlama stresi modelleri kullanılarak oluşturulan mide hasarı araştırmalarına dair çok sayıda çalışma yapılmışıır. Bu sayede gastrik mukozadan prostaglandin E2'nin uzaklaştırılmasının, peptik ülserin gelişmesinde ve ilerlemesinde önemli bir etiyolojik faktör olduğu gösterilmiştir. Tüm bu bilgiler 1şığında, bu derleme ile peptik ülserlerin etiyopatogenezi ve prostaglandin ilişkisinin bir bütün halinde ele alınması ve böylece araştırmacılara gelecek çalışmalara yönelik derli toplu bir bilgi sunulması amaçlanmıştır. Sonuç olarak prostaglandinlerin, stres, hormonal yanıt, mide asidi ve mukus başta olmak üzere bazı ülserojenik ve koruyucu unsurlar ile doğrudan veya dolaylı yoldan ilişkili oldukları ve ayrıca peptik ülser hastalığının tedavisi ile etiyopatogenezinde önemli roller üstlendikleri söylenebilir.
\end{abstract}

Anahtar Kelimeler: Mide, Prostaglandin E2, Stres, Mide asidi, Mukus

usual balance among aggressive factors (acid and pepsin secretion and movement) and defense elements (secretion and effect of mucus and bicarbonate) (2). The etiopathogenesis of gastric ulcer includes various environmental factors such as stress, genetic factors, physiopathological disorders, Helicobacter pylori, alcohol, age, gender, nonsteroidal anti-inflammatory drugs (NSAIDs), trauma, sepsis, hemorrhagic shock and burns (3-6). There is so common knowledge that many endogenous factors, 
including prostaglandin E2 (PGE2), somatostatin, nitric oxide (NO) and sulfhydryl (SH) complexes, are associated with the physiopathology of gastric protection (7). In addition, thus, the mechanism of mucosal damage associated with stress in the stomach is not yet fully understood and clarified (8).

The central nervous system (CNS) communicates with the gastrointestinal (GI) channel through the pathway called the brain-intestinal axis. This axis is a multidirectional transmission tract involving the enteric neural network and the hypothalamicpituitary-adrenal gland (HPA) axis with vagal and spinal afferent and efferent neuronal signals that transmit information to the CNS from the GI pathway and GI system from the CNS; autonomic nerves and CNS (8). Activating of the HPA axis in organisms being submitted to acute mental and physiologic stress causes the release of corticotrophin-releasing hormone (CRH), adrenocorticotrophic hormone (ACTH), endorphins, and corticosterone. Acute stress-induced corticosterone is important in gastric mucosal defense and plays a facilitating role in defense (9). Mucus is a significant defensive agent for the mucosa of the stomach. The mucus, which is in the form of a transparent and viscous gel, consists of $95 \%$ water and $5 \%$ glycoprotein. Mucus may act as a preservative against mucosal antioxidant reduces damage caused by free radicals in the stomach (10). Between the present humoral elements in the mucosa: PGE2, regulation of mucus, and bicarbonate secretion, maintaining the blood flow of the mucosa, acts a significant role in keeping the mucosa by enhancing the strength of epithelial cells versus possible damage caused by cytotoxins (11). In the digestive system, mucus secretion can be organized by prostaglandins (PGs), in particular by PGE2. In addition, various findings suggest that $\mathrm{NO}$ has an effect on the regulation of mucus secretion (12).

\section{Clinical and Research Results}

Stress and Hormonal Response: It should be kept in mind that stress-mediated mucosal lesions can be related to the reduction of gastric mucosal circulation, mainly due to decreased gastric mucosal adaptive mechanisms and changes in blood flow of the visceral zone to vital organs. A reduction in mucosal perfusion can directly induce damage to the gastric mucosa or cause reperfusion injury. In addition, another reason for the mucosal damage in the case of stress is thought to be gastric hypomotility (8). Acute elevation of corticosterone during stress is, in fact, a strong stomach-protective ingredient of hormonal reaction to stress (9). Glucocorticoids cause major changes in the various functions of the organism (13). The protective effect of glucocorticoids is assumed to occur with glucose homeostasis, increased gastric blood flow and mucus secretion, increased gastric motility, and decreased microvascular permeability ( 9 , 14). While glucocorticoids are generally considered to be ulcerogenic hormones, some researchers have suggested that synthesis of glucocorticoids related to activation of the HPA axis effect as gastric-protective hormones. Activating the HPA route can also affect the various functions of the GI path. In response to different psychological and physical stress factors, $\mathrm{CRH}$, secreted from neurons and CRH1 receptors in the parvocellular part of the paraventricular nucleus, induces ACTH secretion out of the front lobe of the pituitary gland. ACTH induces the synthesis of glucocorticoids in the adrenal cortex, such as cortisol and corticosterone in humans. Glucocorticoids cause stress stimulation via CRH, ACTH, b-endorphin, and also additional neurohormones (for example, $\mathrm{P}$ substance, vasoactive intestinal polypeptide, neuropeptide $\mathrm{Y}$ and cholecystokinin), including the GI channel $(8,14)$.

ACTH can stimulate the formation or release of PGs from the adrenal tissue. Some studies have clearly demonstrated that prostaglandin E1 and E2 are a stimulus of cattle adrenal steroidogenesis in vitro. That is still not understood whether these findings relate to human physiology since the effects of PGs on adrenal steroids in humans have not been fully clarified, although PGs are found in human adrenal tissue (15). Some in vitro studies have shown that PGs may also be involved in steroidogenesis control in different ways except direct stimulation (16). Glucocorticoids are effective anti-inflammatory and immunosuppressive drugs that to be efficient on almost all cell types and have complex coactions, depending on the function of many chemical mediators. PGs were considered as targets of glucocorticoid effect in the prolonged process (17). Unlike other PG synthesis inhibitors, such as NSAIDs, glucocorticoids don't directly limit any enzyme of PG biosynthesis. This effect is mainly due to the effects of glucocorticoids and their interaction with nova protein biosynthesis. In vivo studies have shown that glucocorticoids do not alter basal PG secretion in rabbits or healthy human volunteers. While the essential enzymatic mechanisms necessary for the synthesis of prostanoids do not change with glucocorticoid therapy, inducible expression of PG synthesizing enzymes can be inhibited. As a result, basal PG synthesis is not affected by glucocorticoids, but it is sensitive to induction-induced synthesis. This can be indicated in vivo and in vitro (18). In addition, adrenocorticotrophic hormone-induced secretion of noradrenaline in rats has been shown to mediate PGE2 production (19). 
Gastric Acid: Acid secretion of the stomach is necessary for the improvement of gastric mucosal damage, and antisecretory drugs, as a therapeutic possibility, are important in the main effect of the pharmacological manipulation of intraluminal $\mathrm{pH}$. However, it has been suggested that in various species, the decrease of gastric acid secretion occurs as a defense mechanism in stress situations where it is a mediator of a central neuron mediator specifically containing $\mathrm{NO}$ in the dorsal motor nucleus of the vagus nerve (8). The organization of gastric acid synthesis by parietal cells is a significant element in the pathogenesis of peptic ulcer (20). It was observed that in some studies, PGE2 had been shown to respectively increasing the secretion of mucus and $\mathrm{HCO}_{3}$ via EP4 receptors and inhibit acid secretion or mobility by means of EP3 or EP1 receptors (21-25). It has been determined that PGE2 has an inhibitory effect on acid secretion by inhibiting acid secretion directly in parietal cells by EP3 receptors and indirectly limited histamine synthesis in enterochromaffin-like cells (26). Generally, the limitation of acid secretion is a curative aim for the treatment of gastric diseases (27). In the recent years, with the understanding of the importance of $H$. pylori in ulcer etiology and $H$. pylori eradication has been introduced and it has been reported that effective treatment of peptic ulcer disease is possible for the introduction of proton pump inhibitors that make a strong acid blockade (28).

Mucus: Gastric mucus is the first line of defense against acid and acts as a barrier to self-digestion of the stomach with the bicarbonate secreted by the epithelium (29). Administration of various PGs in dogs, rats, and humans has been shown to expose a rapid gastric mucus secretion. In a study of patients with peptic ulceration, it was demonstrated that 15(R)-15-methyl PGE2 methyl ester significantly increased the amount of mucin in mucous cells. The researchers observed that, when PGFzb administered intragastrically to mice, it was soluble and stimulated the release of gel mucin glycoproteins, compared to animals receiving an equal volume of PG at doses previously shown to be cytoprotective (30). In order to play a role in the cytoprotection of mucus secretion, several criteria have to be met before the emergence of such a role. Firstly, it should be shown that the processing of PGs and the doses of PGassociated cytoprotection should elicit mucus release. In several studies examining the cytoprotection and mucus production, the presence of such a correlation has been demonstrated. Secondly, since the cytoprotection occurs within a few minutes after exposure of the gastric epithelium to a damaging substance, the timing of mucus release should be equally rapid. Thirdly, and most importantly, the only open mechanism to which the mucus can offer protection to the mucosa below the gel is that the concentration of the wounding agent forms a vertical gradient so that the luminal side of the gel is much lower than on the epithelium side. In order for this gradient to occur, the mucus gel is almost impermeable to the pollutant, or the substance itself needs to be rapidly removed in the surface cell (31).

The main function of mucus is to mechanically protect the mucosa and underlying mucosal cells and therefore act as a lubricant. Recent advances in bicarbonate secretion of the gastric mucosa have revived the interest in the concept that the continuous release of bicarbonate from the stomach lumen to the epithelium can be an effective block to the action of hydrogen ions from the stomach to the liquid layer mixed with water in the mucus in the jelly in the stomach. In addition to other effects of mucus on the gastric epithelium, PGs also stimulate gastric mucus formation (32). Endoscopically and histologically investigation of the stomach mucosa in patients with good characterized gastric lesions was explained that curing with PGE2 resulted in the improvement of a bubbly mucoid secretion and increased mucus content in mucus-secreting epithelial cells (32). The mucus secreted in the resolvable, or free form can replace denatured or poured wall mucus. The entire freshly excreted primary mucus acts as barrier mucus by adhering to the mucosa. It is also possible that the mucus is not cleaved or fragmented due to the action of acid, pepsin, and local enzymes. Thus, rising in the free mucus piece suggests that the present barrier mucus is poured and changed with newly secreted mucus, and this can be noted as a preservative (33).

Prostaglandins: Endogenous PGs perform the main role in the mucosal protection of the GI tract, of which PGE2 is the most serious in its actions. Endogenous PGE2 has also been reported to be partially responsible for mucosal prevention during cold restriction stress (CRS) by activation of EP4 receptors, further contributing to mucosal protection by PGI2/IP receptors (34). Since CRS-induced gastric damage is a neutrophil-derived (31), it is also possible for indomethacin to increase these lesions by decreasing PGI2 production and promoting the adhesion of leukocytes to the vascular endothelium. In addition, it was known that PGE2 suppresses neutrophil migration by activation of EP4 receptors (35). Neutrophils also play a role in the pathogenesis of NSAIDs-induced gastric injury (36). PGE2 suppresses various neutrophil actions, containing chemotaxis $(35,37)$. In one study, it has been shown that iloprost inhibits CRS-induced gastric lesions primarily by suppression of leukocyte accumulation 
(36). The effect of PGs on some species and human gastric secretion is given in Table 1.

Removing of PGE2 from the gastric mucosa is a considerable etiological agent in the improvement and formation of a peptic ulcer. This system of action can also be due to inhibition of the synthesis of the enzyme cyclooxygenase (COX) activity and synthesis of PGs (39), as well as by the introduction of NSAIDs used to treat common acute and chronic inflammatory diseases (40). Otherwise, gastroprotective actions of some materials that increase gastric mucus secretion have also been reported to be associated with increased PGE2 concentrations in the gastric mucosa $(41,42)$. It has been shown to PGE cause considerable stimulation of gastric mucus excretion, and the effect of PGE on mucus production has been demonstrated to require continued protein synthesis in rats. In this sense, it is probable that the stimulatory effect of PGE on mucus secretion may occur via cAMP, a chemical mediator (43). The success of pharmacological therapies in preventing or treating ulcerative lesions is attached to not only on blocking acid secretion but also on increasing the mucosal preventive factors, including PGs, growth factors, somatostatin, NO, and SH compounds (7). The three functional components, including mucus secretion, microcirculation, and mobility (44) and two humoral factors, including PG and NO (45), are mucosal protective factors.

Necrotizing agents, NSAIDs, and gastric injury models induced by CRS are frequently used to investigate the protective effect of PGE2 in the stomach $(21,35,47-49)$. The effect of NSAIDs on prostaglandin synthesis is known to be a major ulcerogenic mechanism, leading to vascular endothelial damage, reduced blood flow, obstructive micro-thrombus formation, and activation of neutrophils $(50,51)$. In a study, the protective effects of PGE2 on gastric lesions triggered by NSAIDs and CRS were demonstrated (34). It has been shown that CRS $\left(10^{\circ} \mathrm{C}, 90 \mathrm{~min}\right)$ application causes hemorrhagic lesions in the stomach in wild-type mice and that the severity of these lesions worsens in animals treated with indomethacin prior (49). The CRS-induced gastric ulcerogenic response was also observed in EP1 or EP3 knockout (genetic defect) mice, similar to wild-type mice. However, it has been observed that lesions were worsened significantly in the animals lacking prostaglandin I2 (prostacyclin) receptors (52). In particular, children over ten years of age have also been suggested that $H$. pylori infection should be considered an important risk factor for peptic ulcer disease, but this situation is more pronounced for duodenal and antral ulcers. It has also been suggested that due to nonsteroidal anti-inflammatory drugs, peptic ulcer is a more prominent problem in children less than ten years of age (53). In addition, it has been reported that increasing pharmacogenetic information will gain importance in knowing the genetic structure of enzymes related to peptic ulcers and metabolizing drugs before regulating treatment options to patients and regulating treatment accordingly (54).

In addition, it was stated that endogenous PGs originating from COX-1 plays an important role in the maintenance of gastric mucosa against CRS, and this effect may be caused by PGI2 interaction via PGE2 IP receptors, which are particularly mediated by E-type prostanoid receptor 4 (EP4) receptors (34). In particular, relatively large amounts of PGE, F and I species found in the GI mucosa have been found in the gastric mucosa, gastric juice, intestinal mucosa, and intestinal secretions. Although the relative distribution of these PG subgroups varies between different species, it has been suggested that the high PG concentrations in the GI wall may play an important role in gastrointestinal physiology in the gastrointestinal tract. PGs perform locally where they are produced, and even though the source cell of these substances has not yet been clearly identified, enzymes responsible for the biosynthesis and degradation of these substances in the epithelial wall of the stomach have been identified (20). Many studies have clearly demonstrated that PGE, A and I in natural and synthetic forms are potent inhibitors of basal and induced gastric acid secretion in rats, dogs, cats, frogs, and humans when administered orally or topically. Although the protection mechanism of gastric mucosa by PG's was poorly understood, it has been proposed that keeping with "tight junction" between epithelial cells in which the effect of the retaining links. It is necessary to better understand the nature of the gastric mucosal barrier, how such effects of the damaging agents are prevented by the PGs, and how the resistance of the PGs to the degradation of the mucosal barrier develops. It is reported that there is a need for more detailed morphological studies using electron microscopic techniques and clarifying the physical pathways where the mucosal permeability of the stomach changes (31).

Multifactorial etiology, gastro-protection, and physiopathological mechanisms, neurogenic and hormonal stimulations due to stress in peptic ulcer disease and their relationship with PGs are quite complex. In peptic ulcer cases, it is important that glucocorticoids show different effects on acute and chronic processes related to PG synthesis mechanisms. Furthermore, NSAIDs act through PG synthesis inhibition by influencing enzymes related to PG synthesis, which differ from other factors such as 
Table 1. Effect of prostaglandins on gastric secretion in some species and humans. *

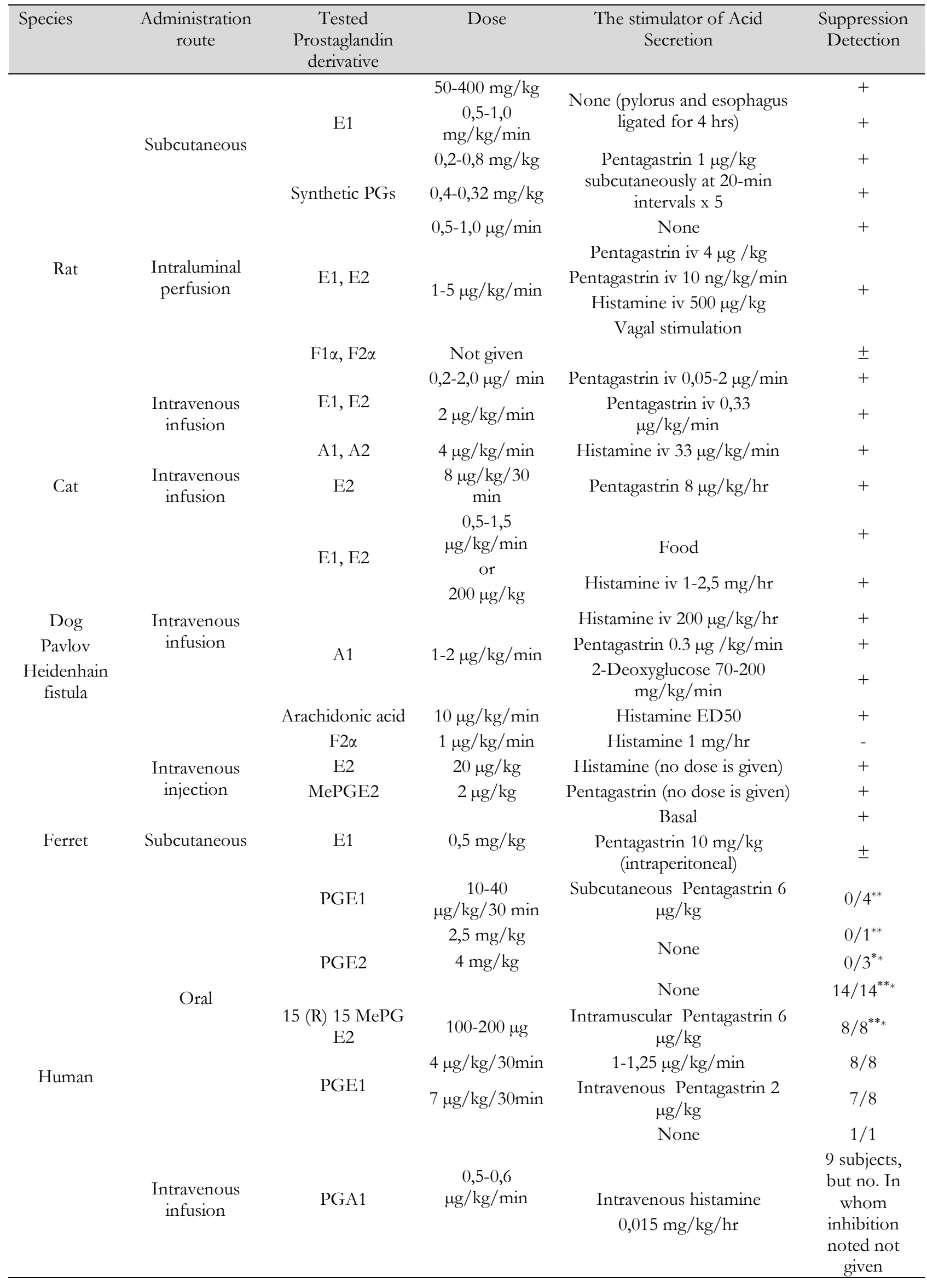




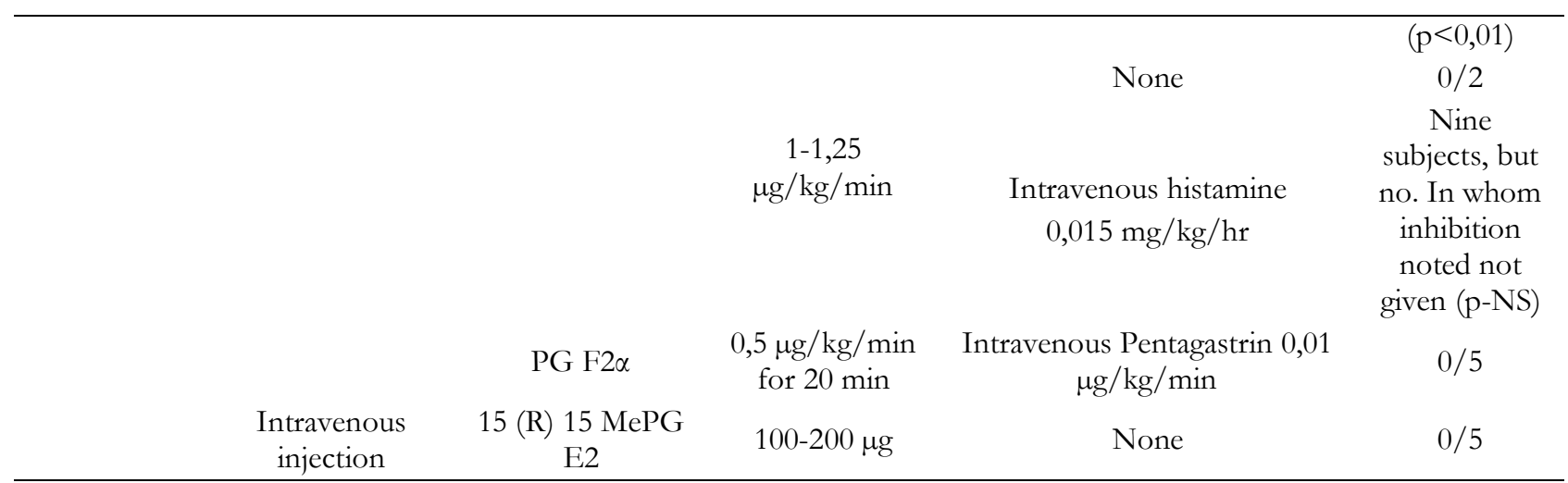

* This table is modified from the Waller, 1973; reference (46).

* A tendency for an enhancement in acid secretion was seen after oral administration of PGE1 and PGE2,

** A rise in $\mathrm{pH}$ was also noted here

cortisone and glucocorticoids. Suppressing of gastric acid and mobility by PGs (mainly PGE2), through increasing mucus and $\mathrm{HCO}_{3}$ secretion; on the other hand, the fact that PGs have a preventive role against neutrophil-induced mucosal damage against cold stress is an important defense against peptic ulcer. It is an undeniable fact that advanced molecular and ultrastructural techniques should be applied in comparative and time-related studies in order to determine how protective effects of PGs occur. In therapeutic applications, all this cause-and-effect relationship should not be ignored. In conclusion, it can be said that prostaglandins are directly or indirectly related to some ulcerogenic and protective factors, especially stress, hormonal response, gastric acid, and mucus, and they also play important roles in the etiopathogenesis of peptic ulcer disease.

\section{References}

1. Crawford AS, White JG. Celecoxib-induced upper gastrointestinal hemorrhage and ulceration. South Med J. 2002; 95(12):1444-1446.

2. Ramakrishnan K, Salinas RC. Peptic ulcer disease. American Family Physician. Am Fam Physician. 2007; 76(7): 1005-1012.

3. Kangwan N, Park J-M, Kim E-H, Hahm KB. Quality of healing of gastric ulcers: natural products beyond acid suppression. World J Gastrointest Pathophysiol. 2014; 5(1): 40-47.

4. Bhagawati S, Sanjay S. Investigations on gastroprotective effect of citalopram, an antidepressant drug against stress and pyloric ligation induced ulcers. Pharmacol Rep. 2011; 63(6): 1413-1426.

5. Taș İ, Ülger BV, Önder A, Kapan M, Bozdağ Z. Peptik ülser perforasyonunda morbidite ve mortaliteye etkili risk faktörleri. Ulusal Cer Derg. 2015; 31: 20-25.

6. Konturek S, Konturek P, Brzozowski T, Konturek J, Pawlik W. From nerves and hormones to bacteria in the stomach; Nobel prize for achievements in gastrology during last century. J Physiol Pharmacol. 2005; 56(4): 507-530.

7. Tsukimi Y, Nakai H, Itoh S, Amagase K, Okabe $S$. Involvement of heat shock proteins in the healing of acetic acid-induced gastric ulcers in rats. J Physiol Pharmacol. 2001; 52(3): 391-406.

8. Gyires K, Fehér Á. Brain-gut relationship on mucosal inflammation in the gastrointestinal tract. In Therapeutic Targets for Inflammation and Cancer: Novel Therapies For Digestive Diseases. 2017; 7-31.

9. Laine L, Takeuchi K, Tarnawski A. Gastric mucosal defense and cytoprotection: bench to bedside. Gastroenterology. 2008; 135(1): 41-60.

10. Repetto M, Llesuy S. Antioxidant properties of natural compounds used in popular medicine for gastric ulcers. Braz J Med Biol Res. 2002; 35(5): 523-534.

11. Hawkey C, Rampton D. Prostaglandins and the gastrointestinal mucosa: are they important in its function, disease, or treatment? Gastroenterology. 1985; 89(5): 1162-1188.

12. Brown J, Keates A, Hanson P, Whittle B. Nitric oxide generators and cGMP stimulate mucus secretion by rat gastric mucosal cells. Am J Physiol. 1993; 265(3): 418-422.

13. Schimmer BP, Funder JW. ACTH, adrenal steroids, and pharmacology of the adrenal cortex. Goodman and Gilman's the pharmacological basis of therapeutics. 12th ed. New-York: McGraw-Hill. 2011: 1209-1235.

14. Özlece HK, Hüseyinoğlu N, Anuk T, Sülü B. Peptik ülser hastalarında sempatik sinir sisteminin elektrofizyolojik olarak değerlendirilmesi. Kafkas J Med Sci. 2014; 4(1): 1-5.

15. Kalinski P. Regulation of immune responses by prostaglandin E2. J Immunol. 2012; 188(1): 21-28.

16. Saruta T, Kaplan NM. Adrenocortical steroidogenesis: the effects of prostaglandins. J Clin Invest. 1972; 51(9): 2246-2251. 
17. Goodwin J. Are prostaglandins proinflammatory, antiinflammatory, both or neither? J Rheumatol Suppl. 1991; 28: 26-29.

18. Goppelt-Struebe M. Molecular mechanisms involved in the regulation of prostaglandin biosynthesis by glucocorticoids. Biochem Pharmacol 1997; 53(10): 1389-1395.

19. Watanabe $\mathrm{T}$, Morimoto A, Morimoto $\mathrm{K}$, Nakamori T, Murakami N. ACTH release induced in rats by noradrenaline is mediated by prostaglandin E2. J Physiol. 1991; 443(1): 431 439.

20. Ribeiro ARS, Diniz PB, Pinheiro MS, Albuquerque-Júnior RL, Thomazzi SM. Gastroprotective effects of thymol on acute and chronic ulcers in rats: the role of prostaglandins, ATP-sensitive $\mathrm{K}+$ channels, and gastric mucus secretion. Chem Biol Interact. 2016; 244: 121-128.

21. Araki H. Roles of prostaglandin $E$ receptor subtypes in cytoprotective action of prostaglandin E_2 in rat stomachs. Aliment Pharmacol Ther. 2000; 14:(1): 116-124.

22. Takeuchi K, Araki H, Umeda M, Komoike Y, Suzuki K. Adaptive gastric cytoprotection is mediated by prostaglandin EP1 receptors: a study using rats and knockout mice. J Pharmacol Exp Ther. 2001; 297(3): 1160-1165.

23. Takahashi S, Takeuchi K, Okabe S. EP4 receptor mediation of prostaglandin E2-stimulated mucus secretion by rabbit gastric epithelial cells. Biochem Pharmacol. 1999; 58(12): 1997-2002.

24. Ohno T, Katori M, Majima M, Saeki T, Boku K, Nishiyama K, et al. Dilatation and constriction of rat gastric mucosal microvessels through prostaglandin EP2 and EP3 receptors. Aliment Pharmacol Ther. 1999; 13(9): 1243-1250.

25. Takeuchi K, Aihara E, Sasaki Y, Nomura Y, Ise F. Involvement Of Cyclooxygenase-1, Prostaglandin E2 and Ep1 Receptots In Acid-Induced HCO3Secretion In Stomach. J Physiol Pharmacol. 2006; 57(4): 661-676.

26. Kato S, Aihara E, Yoshii K, Takeuchi K. Dual action of prostaglandin E2 on gastric acid secretion through different EP-receptor subtypes in the rat. Am J Physiol Gastrointest Liver Physiol. 2005; 289(1): 64-69.

27. Jain KS, Shah AK, Bariwal J, Shelke SM, Kale AP, Jagtap JR, et al. Recent advances in proton pump inhibitors and management of acid-peptic disorders. Bioorg Med Chem. 2007; 15(3): 1181 1205.

28. Tiynak N, Aksoy F, Demiral G, Özçelik A, Şaban B. Perfore peptik ülser olgularında Helikobakter pilori insidansı ve lansoprozol, klaritromisin, amoksisilin ile yapılan üçlü eradikasyon tedavi sonuçları. Akademik Gastroenteroloji Dergisi. 2006; 5(2): 94-99.

29. Allen A, Flemström G. Gastroduodenal mucus bicarbonate barrier: protection against acid and pepsin. Am J Physiol Cell Physiol. 2005; 288(1): 1 19.

30. Szabo S. "Gastric cytoprotection" is still relevant. J Gastroenterol Hepatol. 2014; 29: 124-132.

31. Wang Z, Hasegawa J, Wang X, Matsuda A, Tokuda T, Miura N, Watanabe T. Protective effects of ginger against aspirin-induced gastric ulcers in rats. Yonago Acta Med. 2011; 54(1): 11 19.

32. Fung W-P, Lee S-K, Karim S. Effect of prostaglandin 15 (R) 15 methyl-E2-methyl ester on the gastric mucosa in patients with peptic ulceration-an endoscopic and histological study. Prostaglandins. 1974; 5(5): 465-472.

33. Bolton JP, Palmer D, Cohen MM. Stimulation of mucus and nonparietal cell secretion by the E2 prostaglandins. Am J Dig Dis. 1978; 23(4): 359 364.

34. Takeuchi K, Amagase K. Roles of prostaglandin $\mathrm{E}$ and EP receptors in mucosal protection and ulcer healing in the gastrointestinal tract. Arch Dig Disord. 2017; 1(2): 8-16.

35. Suzuki K, Araki H, Mizoguchi H, Furukawa O, Takeuchi K. Prostaglandin E inhibits indomethacin-induced gastric lesions through EP1 receptors. Digestion. 2001; 63(2): 92-101.

36. 36. Wallace JL, Granger DN. Pathogenesis of NSAID gastropathy: are neutrophils the culprits? Trends Pharmacol Sci. 1992; 13: 129 131.

37. Armstrong RA. Investigation of the inhibitory effects of PGE2 and selective EP agonists on chemotaxis of human neutrophils. $\mathrm{Br} J$ Pharmacol. 1995; 116(7): 2903-2908.

38. Zimmerman BJ, Guillory DJ, Grisham MB, Gaginella TS, Granger DN. Role of leukotriene B4 in granulocyte infiltration into the postischemic feline intestine. Gastroenterology. 1990; 99(5): 1358-1363.

39. Sinha M, Gautam L, Shukla PK, Kaur P, Sharma $\mathrm{S}$, Singh TP. Current perspectives in NSAIDinduced gastropathy. Mediators Inflamm. 2013; 2013: 1-12.

40. Takeuchi K, Tanaka A, Kato S, Amagase K, Satoh H. Roles of COX inhibition in pathogenesis of NSAID-induced small intestinal damage. Clinica Chimica Acta. 2010; 411(7-8): 459-466.

41. Rozza A, Hiruma-Lima C, Takahira RK, Padovani C, Pellizzon C. Effect of menthol in experimentally induced ulcers: pathways of gastroprotection. Chem. Biol. Interact. 2013; 206(2): 272-278.

42. Golbabapour S, Gwaram NS, Hassandarvish P, Hajrezaie M, Kamalidehghan B, Abdulla MA, et al. Gastroprotection studies of Schiff base zinc (II) derivative complex against acute superficial hemorrhagic mucosal lesions in rats. PLoS One. 2013; 8(9): 1-9. 
43. Bersimbaev RI, Tairov MM, Salganik RI. Biochemical mechanisms of regulation of mucus secretion by prostaglandin E2 in rat gastric mucosa. Eur J Pharmacol. 1985; 115(2-3): 259266.

44. Ueki S, Takeuchi K, Okabe S. Gastric motility is an important factor in the pathogenesis of indomethacin-induced gastric mucosal lesions in rats. Digest Dis. Sci. 1988; 33(2): 209-216.

45. Whittle B, Lopez-Belmonte J, Moncada S. Regulation of gastric mucosal integrity by endogenous nitric oxide: interactions with prostanoids and sensory neuropeptides in the rat. Br. J. Pharmacol. 1990; 99(3): 607-611.

46. Waller S. Prostaglandins and the gastrointestinal tract. Gut. 1973; 14(5): 402.

47. Takeuchi K, Yagi K, Kato S, Ukawa H. Roles of prostaglandin e-receptor subtypes in gastric and duodenal bicarbonate secretion in rats. Gastroenterology. 1997; 113(5): 1553-1559.

48. Kunikata T, Tanaka A, Miyazawa T, Kato S, Takeuchi K. 16, 16-Dimethyl prostaglandin E2 inhibits indomethacin-induced small intestinal lesions through EP3 and EP4 receptors. Dig Dis Sci. 2002; 47(4): 894-904.

49. Amagase $\mathrm{K}$, Izumi $\mathrm{N}$, Takahira $\mathrm{Y}$, Wada $\mathrm{T}$, Takeuchi K. Importance of cyclooxygenase- $1 /$ prostacyclin in modulating gastric mucosal integrity under stress conditions. J J Gastroenterol Hepatol. 2014; 29: 3-10.

50. Guth PH. Current concepts in gastric microcirculatory pathophysiology. Yale J Biol Med. 1992; 65(6): 677.

51. Kılıçarslan H, Kalyon S, Yenice N. Peptik ülser etyopatogenezi. Okmeydanı Tip Dergisi. 2011; 27(2): 65-69.

52. Narumiya S, FitzGerald GA. Genetic and pharmacological analysis of prostanoid receptor function. J Clin Invest. 2001; 108(1): 25-30.

53. Çam S. Pediatrik peptik ülser hastalığı önemli mi?. Düzce Tıp Fakültesi Dergisi. 2015; 17(3): 133-135.

54. Kara H, Göktaş MT. Gastroenteroloji Alanında Farmakogenetik Bilginin Kullanılması. Ankara Med J. 2016; 16(2): 232-238. 